\title{
Downtown revitalization: The Kitchener experience
}

\author{
George Borovilos, Ec.D.
}

Downtown revitalization is clearly in the minds of many communities throughout North America. The driving force behind this agenda is the belief that downtown is the lifeblood of the city. However, since the Second World War, people and businesses have moved out of the downtown to the suburbs. This paper reviews what has caused this historic pattern of decline and outlines the various myths and approaches that communities have employed in revitalizing their downtown. The City of Kitchener's strategy for downtown revitalization is examined as a case study, concluding that lasting economic and social recovery for a downtown will come only when there is a collective vision implemented through an incremental approach.

Keywords: downtown revitalization, urban, suburban, City of Kitchener

\section{Introduction}

Downtown Revitalization is clearly in the minds of many communities throughout North America. The driving force behind this agenda is the belief that downtown is the lifeblood of the city. William Whyte (1980) observed:

"The street -- particularly in the centre city -- is among the greatest of cultural legacies. It is the river of city life. It gives the city continuity and coherence. It defines its scale. But it under attack."

Growth in the suburbs has resulted in people and businesses moving out of the downtown. This trend has continued since the Second World War. The challenge in Downtown Revitalization is to get people to rediscover the centre of their community, to create a place for people to come together. It is recreating the magical feeling that Walt Disney has achieved in Magic Kingdom's Main Street.

In this paper, we review what has caused the historic pattern of decline, and then we outline the various myths and approaches that communities have employed in revitalizing their downtown. We also review the Main Street approach and specifically examine the City of Kitchener's strategy for Downtown Revitalization.

\section{Downtown decline - the reality}


The overall hypothesis is that the downtown has been drained of its vitality in the post-World War II decades by suburban residential and commercial growth. This has been driven to a large extent by the expanded capabilities of linkage systems related to transportation and communications. The reality is that families and businesses have gained unprecedented freedom in location. The result is that they have choice in deciding their spatial arrangement (Grava, 1998). Whether we can or should do something about it is open for debate (Krohe, 1999; Robertson, 1999).

Unfortunately the image of what a downtown should look like, and the images we carry in our heads, are from a previous era. Whether this is good or bad remains a question for further discussion. The current situation is that image is not a reality. For example, the most striking feature of the downtown of the past was the retail component along Main Street. Today that retail environment is under attack. The old shopping streets are identifiable, but the empty retail buildings and the vacant show windows give a sad testimony to the power of suburban malls, high-volume discount houses, big boxes, and e-retailing. Retail has followed where people live, and although there are exceptions, the holdouts represent family-owned businesses passed on from one generation to the next.

Beyond the changing retail fabric, the rest of downtown has uses that are similar from place to place and consist of uses that have been there historically. In the Central Business District, there remain government offices, city hall, courthouses, business offices, hotels and other relevant social service agencies. For example, old towers and new towers built in the 1980s and early 1990s represent the multi-story office buildings. The occupants of these high-rise towers represent corporate establishments such as banks, insurance companies, and other similar organizations. The office workers have a minimal interest in the rest of the core. The pattern is similar - park in parking garages that are attached directly to their buildings or a short walking distance away from them. Lunch places are located in the office structures or are in near by locations. The reality is that they leave by 5:00 p.m.

Hotels are also part of the downtown landscape. They tend to be multi-story and clearly serve business and government travelers, as opposed to families of tourists. In many cases these structures are physically connected to the secure downtown passageway systems. Religious buildings are another traditional part of the Downtown with their majestic cathedrals as dominant features.

This transformation has not happened without a struggle (Moe and Wilkie, 1999; Gratz and Mintz, 2000). Political and business leaders have taken steps to deal with this decline. Traditionally downtowns undergo various stages of crisis and intervention, but fail to address fundamental issues that will have a sustainable lasting positive effect in the core. Typically many groups, organizations and individuals feel that time pressures and constraints force them 
into undertaking "Band-Aid" solutions to fix a perceived problem, which they believe will set a positive course for downtown rehabilitation. A number of approaches have been developed in the past few decades; these are outlined in the following section.

\section{Downtown revitalization myths}

Since the advent of suburbanization of the downtown during the 1960s and 1970s, a number of different approaches to Downtown Revitalization have emerged in response to the related problems of businesses leaving, crime, and other social-related issues. In the past 20 years, many communities have attempted to address these problems and have pursued ways to lure businesses and people back into their downtown areas (Palma and Hyett, 1992; Palma, 1995; Goldberg, 1998).

Strategies to spur Downtown Revitalization include such things as arenas, theatres, convention and trade centres, downtown malls, streetscape improvements, parking structures, urban entertainment complexes, and new forms of residential and tourism development. These approaches recognize that part of the evolution of downtowns from their previous prime retail function to new uses that serve different markets present new planning and economic issues for the core areas. However, the uncertainty comes in assessing the costs and benefits of projects, getting the mix right, and strategically encouraging incremental but lasting positive change. Clearly there is no magical formula.

Research has uncovered a number of common misconceptions about how communities and organizations make serious mistakes in terms of downtown redevelopment. Palma (1995) has outlined a number of Downtown Revitalization myths. These myths provide an important insight into planning and development as to how communities should think in terms of reviving a downtown and preparing an effective revitalization program.

\section{Myth one: if we built it they will come}

This belief is that a community only needs to undertake physical improvements for customers and investors to flock to the downtown. Physical improvements can be on two levels: the first is related to improvements to the streetscape, while the second one is related to massive physical projects. In terms of physical improvements to the shopping environment, a number of common features are prevalent throughout North American downtowns. These improvements range from creating malls downtown, widening and paving of sidewalks, provision of landscaping, new street furniture and artwork places, well-designed lampposts, and the provision of bus shelter and sitting areas. At the other end are the large physical improvement projects. Unfortunately, physical improvements made on a grand scale and in isolation do not result in renewed downtown vitality. 


\section{Myth two: If they demolish it they will come}

This approach involves the demolition of old buildings, clearing and assembling land so that developers will flock to the downtown. The reality is that many communities that have tried this approach have ignored the obvious that bulldozing and clearing an area does not attract developers to a downtown whose market is weak. In fact, communities are recognizing that structurally sound old buildings, no matter how run down they look, can often become a tremendous draw if they are renovated and their architectural character preserved.

\section{Myth three: The silver bullet approach}

In this approach, a community identifies and implements one major project, the assumption is that then everything related to the downtown will take care of itself. Examples are prevalent throughout North America - downtown convention centres, festival marketplaces, urban entertainment complexes, parking structures, or pedestrian malls in isolation (Hunter and Bleinberger, 1996; Miller, 1997).

\section{Myth four: Traditional anchor store}

This approach is predicated on the historical belief that a downtown needs a department store in order to be healthy. The loss of Eaton's, a retail icon in many Canadian downtowns, reinforces this notion. The traditional anchor approach to Downtown Revitalization is of value, but it requires a new interpretation of the definition of anchor. New anchors include cultural facilities, government complexes, entertainment facilities, tourist attractions, housing units, professional office buildings, and specialty shops. By promoting and leveraging these new anchors, communities can experience renewed downtown regeneration.

\section{Myth five: Lack of big retail}

The Big Retail or No Retail Approach suggests that if a community cannot get a department store to locate downtown, then a downtown can no longer support any kind of retail trade. This theory ignores the fact that a healthy downtown must also contain small retail trade activity. Niche retailing brings character back to the street and encourages pedestrian activity.

\section{Myth six: Head in the sand}

This particular approach ignores the fundamental marketing concept that similar and compatible businesses located in convenient groupings often expand and magnify the market for that cluster. 
The cluster is more appealing in terms of convenience and variety than occurs with a single, isolated business.

\section{Myth seven: Let's pretend we're a mall approach}

For downtown to be successful, retail businesses should keep uniform business hours. Attempts to standardized store hours like a shopping mall have proven to be more divisive than positive, given the independent nature of downtown business owners. An alternative strategy is to think strategically about "market-driven business hours" e.g., hours that best meet the needs of targeted consumers. Smarter hours rather than longer hours that are convenient for customers are critical in maintaining a market edge for the independent retailers.

\section{Myth eight: More parking}

This is the classic scapegoat approach that suggests that all downtown ills stem from a lack of parking. It has been argued that customers left the downtown for shopping malls because malls offer customers acres of parking. For many downtowns the parking problem is one of parking management rather than one of parking supply. The number of parking spaces available is adequate, but the difficulty in finding a spot is because downtown employees are parking in spaces nearest the business, and the public parking facilities are not clearly marked with signs (Barr, 1997).

The myths outlined provide a valuable insight into the common pitfalls of approaching a Downtown Revitalization plan. Understanding the dynamics and principles behind them may prove to be a critical step in making the necessary shift to create positive change.

\section{Main street approach to downtown revitalization}

While, as noted above, Downtown Revitalization can be addressed in many way, the Main Street approach advocates a return to community self-reliance, empowerment, and the rebuilding of the Central Business District based on its traditional assets: historical architecture, customer service, local ownership, and a sense of community (Ehrenhalt, 1996; Dane, 1997).

A number of communities across North America have implemented this type of incremental approach, one that is not designed to produce an overall, immediate change. Main Street requires careful attention to every aspect of downtown, a process that takes time and requires leadership and local capacity building. Both the public and private sectors of the community must be involved and committed for this approach to succeed. Each sector has an important role to play and each must understand the other's needs, strengths and limitations so that an effective partnership can be created. 
The success of the Main Street approach is based on eight underlying principles (National Main Street Center, 2000):

Comprehensive:

Incremental:

Self Help:
A single project cannot revitalize downtown. An ongoing incremental approach to downtown revitalization is required.

Small projects make a difference. They demonstrate that "things are happening". This to helps develop the expertise to tackle more complex problems. Over time, these small changes make a dramatic difference in a downtown.

Local leadership will bring long-term success by fostering and demonstrating grassroots community involvement and building local capacity entrepreneurism and commitment to the revitalization effort.

Public/private partnership: The support and expertise of both the public and private sectors are required in the effort to revitalize downtown. assets:

Quality:

Change:

\section{Capitalizing on existing}

Change:

\begin{abstract}
The importance of local communities to recognize and make the best use of their unique attributes. Local assets provide the solid foundation of a successful Main Street initiative.
\end{abstract}

From storefront design to promotional campaigns to graphics to special events, quality must be the goal. The local Main Street program and downtown must be synonymous with quality and personal service.

Changing community attitudes and habits is essential to bring about a downtown renaissance. A carefully planned Main Street program will help create paradigm shifts that change public perceptions and practices to support and sustain the revitalization process.

Frequent visible changes in the look and activities of the downtown will reinforce the perception of positive change. Small, but dramatic improvements early in the process will remind merchants and the community that the revitalization effort is under 
way. This requires the hands-on involvement of politicians, staff, volunteers and the private sector.

Downtown Revitalization approaches over the past 20 years suggest that no single project, no one grand solution will lift a downtown from decline and put it on the road to permanent prosperity. Lasting economic and social recovery for downtown will come only when all the interest groups agree to share their views and listen to the views of others. This also means that Downtown Revitalization cannot be done with the Main Street approach alone. Interdependence between the strategy of major "block" redevelopment projects and physical improvements must be done in conjunction with the incremental Main Street approach.

\section{Downtown Kitchener}

The City of Kitchener is situated in southwestern Ontario, a one-hour drive west of Toronto. Downtown Kitchener in the 1960s was the Central Business District for the larger regional area. With the growth of the city's suburbs and the changing retail landscape, Downtown Kitchener's competitive position within the regional economy began to erode throughout the 1970s and 1980s. By the 1990s, Kitchener's downtown clearly showed the effects of suburbanization. As Grava (1998) has indicated there are hundreds of different places experiencing the same change, accompanied by considerable pain. Kitchener was no exception.

By the mid-1990s, Downtown Kitchener was at a crossroads. It was time to make a change or the downtown would become obsolete. The option of doing nothing to facilitate growth would eventually lead to more costly and difficult problems. It was clearly recognized that Downtown Kitchener presented new planning and economic issues. The uncertainty as to what to do comes in assessing the costs and benefits of projects, getting the mix right, and strategically encouraging incremental but lasting positive change.

Like most communities experiencing problems with their downtowns, Kitchener went through a report phase trying to come up with an effective solution to Downtown Revitalization. Two major land use plans and a host of lesser studies were prepared over the years, some dating from early in the last century.

\section{Thomas Adams plan 1914}

This plan proposed major changes. Completed in 1914, this plan was based on a European style layout with radial streets and grand avenues. Civic beauty was the emphasis of this optimistic vision. Unfortunately the plan was abandoned at the onset of the First World War, with few tangible consequences. 


\section{The plan - downtown Kitchener 1965}

The second and more influential report known as The Plan - Downtown Kitchener was presented in 1965 (The Urban Renewal Committee, 1965). It envisioned turning King Street into a pedestrian covered mall anchored by large department stores. Parking garages would be built on a perimeter ring road system and no vehicles would be allowed in the core. Offices, stores and hotels would surround the mall, interspersed by parking garages and encompassed by a ring of apartments beyond the ring road system.

It was anticipated that government buildings would move to an adjacent Civic Square to augment the existing library, old jail and County buildings. To complete this vision, $\$ 50$ million in federal urban renewal funding was expected but only about $\$ 1$ million was actually received.

In order to implement this plan, parking was banned on King Street and replaced with the Duke and Ontario Streets parking garage, which opened in 1967. This plan also formed the basis of the 1971 decision to build Market Square and demolish the old City Hall. The second anchor, King Centre Mall, was completed in 1980, with a parking garage on the perimeter road as proposed in 1968.

The reality was that the construction of the King Street mall never took place, however the concept remained and has influenced Downtown land use planning ever since. Other features of the plan included the reduction of King Street to one lane; elimination of on-street parking and the frequent closing of King Street as a venue for special events remained the norm. Unfortunately, the expected population growth never occurred and the high residential density around the core was never built. Another consequence of the urban development process was that King Street businesses were not able to compete with the malls and lost their dominant position. The increasingly footloose population had choice.

\section{Kitchener downtown study 1981}

Things began to change in 1981 with the Kitchener Downtown Study by Woods Gordon (Woods Gordon, 1981). The key finding behind this study was that it identified the Downtown as still constituting the prime retail area of the Region. It did reject the idea of a covered mall as expensive and impractical. Alternatively it suggested a King Street transit mall and special event programming to stimulate an image of excitement and interest. It also stressed the need for residential development to maintain a local retail market and evening population. It suggested that the City should discourage retail, commercial and major office development outside the Downtown. 


\section{Downtown revitalization plan 1987}

In 1982, the King Street pedestrian mall concept was officially shelved. Council subsequently discussed the need for a new City Hall on King Street and in 1987 moved the transportation centre to a more central location in the core. The 1987 Revitalization Plan approved these changes, and also advocated completion of the ring road, increased housing, a new parking structure and traditional landscaping features such as statues, fountains and courtyards (Downtown Revitalization Plan, 1987).

\section{Kubas consultants study 1987}

The trend pointed out in the Downtown Revitalization Plan was noted in the Kubas Consultants study, which recognized that the downtown must offer a different experience from malls. The study also underscored the urgency to change the public image in terms of the physical, social and cultural environment. It also pointed out that retailers and shoppers alike cited the issue of parking availability and its cost as a central concern. During this period the downtown retail sector continued to decline, a trend that has accelerated since 1990 (Kubas Report, 1997).

\section{Kitchener downtown business association (KDBA) retail action plan 1995}

This study indicated that street redevelopment would require re-positioning and remerchandising of the retail component. It suggested that downtowns have an advantage over existing malls and new format malls, in that the aging baby boomer is seeking a nostalgic return to the "good old days". The Retail Action Plan suggested developing a repositioning strategy around destination attractions. This would create critical mass in the west, central and eastern clusters of the downtown (KDBA Retail Action Plan, 1995).

\section{Downtown strategic plan 1999-2001}

\section{Themes}

Although the aesthetic appeal of a strong city centre is important in terms of street vendors, urban life and natural gathering tendencies of people to see and be seen, the return to the many elements of the 1950s core city area is a concept that hopefully allows a downtown to take on its own character and evolve naturally. The fountain and the skating rink at the Kitchener City Hall illustrate this new sense of direction.

Going beyond the physical improvement approach to Downtown Revitalization is the need to examine other key factors. These factors comprise many complex pieces interwoven in a symbiotic relationship with one another. In terms of Downtown Kitchener there are five themes 
which create the new vision required to re-position this complex environment (Downtown Strategic Plan 1999-2001).

The five themes are:

- housing;

- bring people downtown;

- support business;

- physical environment;

- neighbourhood/community development.

These themes reflect the learning experience of the past studies and demonstrate the complexities and interrelationships, which are involved in the Downtown Revitalization process.

\section{Housing}

Throughout North America, housing has played an important part in downtown development. Housing attracts people downtown, creates activity, and provides a customer base for retail and entertainment businesses. It also provides an opportunity to develop a sense of neighbourhood and community ownership in the downtown.

\section{Bring People Downtown}

Another important element in creating a vibrant and successful downtown is the need to bring people to visit and spend their free time and disposable income. Downtown must provide an experience whereby suburbanites are encouraged to visit and make return trips. One way to achieve this type of repeat experience is through arts and culture (Cardinal Concepts, 1996).

\section{Support Business}

Most downtowns have a business and administrative function. Creating a place that is unique and reinforces the needs of the office users and specialty retailers are critical in shaping this type of environment (Pavy and Wagner, 1993; Brooks and Kushner, 2001). Downtown cannot compete with a suburban mall, however lower rents and common area maintenance charges, in combination with the creation of the right environment for these shops, will strengthen this niche. 


\section{Physical Environment}

Creation of an environment that is pleasant and safe is still an essential ingredient in Downtown Revitalization. Physical improvements such as entrance features, pedestrian-friendly lighting, christmas decorations, decorative sidewalks and fixtures are examples that contribute to an individual sense of place. The importance of creating a unique, interesting, safe and comfortable environment is important in attracting the number of people that come to the downtown in order to experience this exciting new environment.

\section{Neighbourhood/Community Development}

Real communities are based on a common attribute of a healthy downtown. The manicured, homogenous suburban images stand in stark contrast to the diversity of the downtown. By recognizing downtown as a neighbourhood, a sense of community develops, that increases the level of personal attachment to place. This attraction builds a positive and successful neighbourhood, and therefore downtown.

\section{Districts}

Given the size of Downtown Kitchener, the number of blocks which make up Kitchener's downtown, and the political and business commitment to make change, Kitchener has embarked on a major capital investment in three downtown areas - the east end, the warehouse district and the centre core. The three major clusters form distinctive districts within the geographic area of Downtown Kitchener.

In order to undertake this capital investment, the City of Kitchener designated the Downtown as a community improvement area under Section 28 of the Ontario Planning Act. This will allow a municipality to bonus private development provided the Minister of Municipal Affairs and Housing approves the plan.

Under the community improvement section of the Planning Act, a municipality can assemble lands not only for the reason of physical deterioration but also for the broader public interest, which includes social, and economic renewal objectives. Financial incentives can also be provided. The City of Kitchener has developed a variety of financial incentives to stimulate Downtown redevelopment. Examples include - tax rebates; funding for feasibility studies; rebates for planning and building permit fees; waiving of City development charges; waiving of park dedication fees; and the façade/interior loan program. 


\section{The East End}

At the eastern entrance to downtown two major elements have been developed. First, is the east market where the Kitchener Farmers' Market and the many ethnic and food stores exist. This area serves as a neighbourhood shopping area for the adjacent neighbourhoods and office community. Coupled with this area is Market Village, which provides specialty shopping within a village ambiance of narrow streets and detached dwellings converted into storefronts and bistros.

The City announced plans to build a new urban market after extensive public consultation with the objective of reinforcing the East End. The proposed mixed-use development will include retail stores, vendors, and a residential component.

The rationale behind moving the market out from the basement of Market Square was to create "a stand alone" facility close to the original location. The new location would be more conducive to pleasure shopping and help revitalize the market itself for local residents and potential tourists. In addition, it would enable the market to recapture some of the businesses lost to competing markets in neighbouring Waterloo and St. Jacobs.

\section{The Warehouse District}

Located at the west side of Downtown Kitchener, this district comprises large, old industrial buildings that are being converted into an eclectic community of artist live/work spaces, loft apartments, galleries, antique shops, and incubators for new businesses. The conversion of one property to high-tech office space reinforces the potential of this area to create an environment that is well suited to meet the requirements of today's telecommunications-related businesses. The infrastructure of older buildings lends itself to large floor plates, ample power, and close proximity to fibre optics (Bendit, 2000).

The City's commitment has been in the form of capital improvements to the roads, lighting, sidewalks and other streetscape improvements. This will provide an opportunity to theme the area and create an 18-hour environment.

\section{The Centre Core}

This area is extensively mixed with hotels, offices, restaurants and convenience retail. Although there has been improvement in this area, the City purchased a number of properties to stop the physical deterioration and negate the pervasive social blight, which characterized it. The multimillion dollar purchase of properties has provided an opportunity for the City to make significant 
changes in the Downtown. The repositioning of these properties will provide an opportunity to develop a mixed residential, retail, arts and cultural area.

The rationale behind this "block" redevelopment process is to reinforce the existing "carriage trade", and bring new housing opportunities into the central part of the core. This site will also provide a catalyst for repositioning the adjacent blocks.

\section{Policy recommendations}

Successful Downtown Revitalization requires an approach that is incremental. Expensive improvements often fail to address the underlying causes of a decline in a downtown and do not always produce the desired economic results. If a long-term revitalization effort is to succeed, it will require careful attention to every aspect of downtown, a process that takes time and requires leadership and local capacity building.

From a policy perspective, a number of recommendations are put forth:

\section{One vision}

Downtown Revitalization requires the efforts of the entire community to work in a symbiotic relationship. All the parts have to work in harmony for a community's efforts to produce positive impacts. The merchants, property owners, local government officials, and civic leaders must agree to support common goals for revitalization. There must be a buy-in to one common vision.

\section{Incremental}

The decline of a downtown did not happen overnight. It took a number of years, and therefore, realistic change to achieve sustained economic results will take a significant time period. Changing community attitudes and habits is essential to bring about Downtown Revitalization. Creating a paradigm shift that changes public perceptions and practices to support and sustain the revitalization process requires a careful planned approach.

\section{Promotion}

Downtown promotion should be conducted as part of a single, unified commercial area in the same way that a major shopping mall is promoted. This will help attract customers and strengthen a downtown. This involves a coordinated promotion and marketing campaign that includes a program of special events and business promotions. Downtown must also improve both its self-image and the image projected to potential customers and investors. 


\section{Design}

Another essential requirement in Downtown Revitalization is the importance of good design. This does not necessarily mean a "purist" preservation approach, but rather exploring ways that utilize and enhance those elements of quality design that is inherent in buildings. Good design also applies to street amenities, public building improvements, and store windows and merchandise displays.

\section{Re-Positioning}

While many downtowns may not regain their dominance as primary retail centres, careful marketing and economic analysis can be used in diversification strategies that complement the present mix of retail uses by attracting new retail and non-retail functions. These can include office, residential, recreational and arts and cultural uses. This may also involve the development of effective merchandising techniques, reuse of upper stories for downtown housing and office space, and retail and business retention and recruitment initiatives.

\section{Public/Private partnership}

Downtown Revitalization strategies require communities to commit public funds to projects that support local business, attract people, and reinforce the downtown neighbourhoods. Involvement of the public sector, will instill confidence in the private sector to re-invest in Main Street.

\section{Conclusion}

It has become evident that no single project, no one grand solution will lift downtown from decline and put in on the road to permanent prosperity. Lasting economic and social recovery for a downtown will come only when there is a collective vision implemented through an incremental approach. What has clearly emerged as a result of many studies and approaches to Downtown Revitalization is that the core or the old Central Business District still remains the symbolic centre of the urban community. The reality however, is that the downtown no longer relates directly to the daily lives of the residents except for those who work there or live there. The challenge is to recapture the vitality of the street. A successful street in the downtown has a critical mass of activity and of people. The street is the gathering place for people to interact. In other words, downtown must provide an experience to the visitor and resident alike. Only then will it be able to be a legitimate alternative urban experience. 


\section{Author's biography}

George Borovilos is Director, Economic Development, City of Kitchener, a position he has held for the past ten years. George Borovilos holds a B.E.S. (Bachelor of Environmental Studies, Geography) from the University of Waterloo and a M.A. (Master of Arts in Urban Planning) from the University of California, Los Angeles. He received his Certified Economic Developer designation (Ec.D.) in 1992. George has been actively involved in the design and delivery of educational courses and seminars for the Economic Development Program since 1989.

\section{Bibliography}

Barr, Mary, Downtown Parking Made Easy: 6 Strategies for Improving the Quality and Quantity of Downtown Parking, New York: Downtown Research and Development Center, 1987.

Bendit, Charles, "Industrial Properties - Anchors for a Wired Nation," Area Development, October 2000, pp. 46-50.

Brooks, Arthur C. and Roland J. Kushner, "Cultural Districts and Urban Development," International Journal of Arts Management, Vol. 3 (2), Winter 2001. pp. 4-15.

Cardinal Concepts, A Cultural Strategic Plan for Kitchener, June 1996.

City of Kitchener: Downtown Revitalization Plan, November 1987.

City of Kitchener: Mayor's Task Force on the Downtown, June 1995.

City of Kitchener, Downtown Strategic Plan-1999 to 2001.

Dane, Suzanne, Main Street Success Stories, Washington, DC: National Main Street Center, National Trust for Historic Preservation, 1997.

Ehrenhalt, Alan, “Return to Main Street,” Governing, Vol. 9, May 1996, pp. 18-19.

Goldberg, Jeff, "Breathing New Life into Cities", The Futurist, Vol. 32(8), Nov. 1998. 14 pp.

Gratz, Roberta Brandes and Norman Mint, Cities Back from the Edge: New Life for Downtown, New York: John Wiley, 2000.

Grava, Sigurd, The Old Downtown, It Ain't What it Used to Be, http://sipa.columbia.edu/RESOURCES/CU.../v01n0405_txt.htm, 1998. 
Hunter, Donald E. and Ernest E. Bleinberger, "Urban Entertainment Centers," Public Management, March 1996. pp. 4-9.

Krohe Jr., James, “Is Downtown Worth Saving?”, Planning, August 1992, pp. 9-13.

Kubas Consultants, Progress and Development in Downtown Kitchener and the Role of KDBA, July 1987.

Miller, Glenn, "Urban Entertainment Centres: Anchor-Scale Developments that are Larger than Life”, Ontario Planning Journal, Vol. 12(1), January/February, 1997, pp. 3-4.

Moe, Richard and Carter Wilkie, Changing Places: Rebuilding Community in the Age of Sprawl, New York: Henry Holt \& Co., 1999.

Palma, Dolores and Doyle Hyett, Downtown Safety: Addressing the Myths and the Realities, Alexandria, VA: HyettPalma Publications, 1992.

Palma, Dolores, “Downtown Revitalization.” Commentary, Summer, 1995. pp . 23-29.

Palma, Dolores, "Effective Strategies for a Safe Downtown”, Municipal Maryland, Vol 24(7), February 1995, pp. 8-10.

Palma, Dolores and Doyle Hyett, "Anchors Reinvent Downtowns." American City and County, Vol. 114(6), June, 1999, p. 56.

Pavy, Manon and Fritz Wagner, "Focusing the Old Downtown on Specialty Retail for Economic Survival: The Transition of Ponchatoula, Louisiana.” Small Town, Vol. 24(3), November/December 1993. pp. 18-23.

Revitalizing Downtown, The Professional's Guide to the Main Street Approach, Washington, DD. National Main Street Center, National Trust for Historic Preservation, 2000.

Robertson, Kent A., “Can Small-City Downtowns Remain Viable?”Journal of the American Planning Association, Vol. 65(3), Summer 1999. pp. 270-283.

The Urban Renewal Committee, The Plan-Downtown Kitchener, 1965.

Thomas Consultants International Inc., KDBA Retail Action Plan, 1995. 
Woods Gordon, Kitchener Downtown Study, December 1981.

Whyte, William, “The Humble Street”, Historic Preservation, January 1980, pp. 34-41 
